\title{
Randomised trials of temperature management in cardiac arrest: Are we observing the Zeno's paradox of the Tortoise and Achilles?
}

\author{
Tommaso Scquizzato ${ }^{1}$, Paul J. Young ${ }^{2}$, Giovanni Landoni ${ }^{1,3^{*}}{ }^{\mathbb{D}}$, Luisa Zaraca ${ }^{1}$ and Alberto Zangrillo ${ }^{1,3}$
}

\section{To the Editor,}

Initial trials published in 2002 found a benefit of therapeutic hypothermia at $32-34{ }^{\circ} \mathrm{C}$ in comatose adults resuscitated after cardiac arrest $[1,2]$. Two decades after the publication of these practice-changing trials, a large multicentre randomised clinical trial (mRCT) found no benefit of temperature control at $33{ }^{\circ} \mathrm{C}$ compared to normothermia with active treatment of fever [3].

$\mathrm{mRCTs}$ performed in critically ill patients frequently do not confirm the positive findings of smaller or single-centre RCTs (sRCTs) [4]. Early positive studies on hypothermia had many methodological shortcomings, including no power calculations, small samples, unblinded assessors, nonstandard neuro-prognostication, and discontinuation because of funding lack. Moreover, the control group experienced fever, and it was unclear if improved outcomes were attributable to hypothermia or fever avoidance. Therefore, beneficial effects of hypothermia might be overestimated or could represent type 1 errors. In contrast, recent studies had lower risk of bias, larger samples, and higher methodological quality. The TTM2 trial enrolled five times more patients than earlier trials combined, minimised premature withdrawal of care, applied rigorous prognostication guidelines, protocolised care, and actively treated fever in both groups $[3,5]$.

Are we observing the Zeno's paradox of the Tortoise and Achilles? In this paradox, Achilles is racing with a Tortoise with a head start. According to Zeno, Achilles will never reach the Tortoise, as every time Achilles reaches where the Tortoise was, the Tortoise moved forwards. Are the earlier, small, often sRCTs on temperature management the Tortoise and the recent, large, mRCTs Achilles? The more powerful mRCTs (Achilles) continuously chase sRCTs (Tortoise), but they cannot reach them and always arrive later, often with different findings and unavoidable delay. Since the publication of earlier studies, treatments improved (i.e. coronary angiography, standardised haemodynamic/ventilatory targets, early withdrawal avoidance) and may have influenced intervention effects. Moreover, differences between treatment and control are progressively muffling due to parallel treatments competing with the studied intervention. Consequently, patients needed to enrol and the power is never sufficient.

The Zeno's paradox may initially reflect the clinical trials reality where mRCTs (Achilles) never reach sRCTs (Tortoise). However, it does not, just like in the real world where Achilles can reach the Tortoise. Slowly and painfully, mRCTs can reach and confirm the findings of sRCTs and, when it occurs, worldwide clinical practice changes. Until that happens, the positive findings of sRTCs should be interpreted cautiously, unless confirmed by high-quality mRCTs, particularly when such studies are unblinded.
*Correspondence: landoni.giovanni@hsr.it

1 Department of Anesthesia and Intensive Care, IRCCS San Raffaele Scientific Institute, Via Olgettina, 60, 20132 Milan, Italy

Full list of author information is available at the end of the article

\section{Abbreviations}

mRCT: Multicentre randomised clinical trial; SRCT: Single-centre randomised clinical trial; TTM2: Targeted hypothermia versus targeted normothermia after out-of-hospital cardiac arrest.

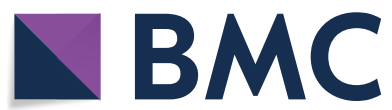

(c) The Author(s) 2021. Open Access This article is licensed under a Creative Commons Attribution 4.0 International License, which permits use, sharing, adaptation, distribution and reproduction in any medium or format, as long as you give appropriate credit to the original author(s) and the source, provide a link to the Creative Commons licence, and indicate if changes were made. The images or other third party material in this article are included in the article's Creative Commons licence, unless indicated otherwise in a credit line to the material. If material is not included in the article's Creative Commons licence and your intended use is not permitted by statutory regulation or exceeds the permitted use, you will need to obtain permission directly from the copyright holder. To view a copy of this licence, visit http://creativecommons.org/licenses/by/4.0/. The Creative Commons Public Domain Dedication waiver (http://creativecommons.org/publicdomain/zero/1.0/) applies to the data made available in this article, unless otherwise stated in a credit line to the data. 


\section{Acknowledgements}

None.

\section{Authors' contributions}

All authors participated in study concept and design, drafting the manuscript, and approved the final version.

\section{Funding}

None.

\section{Availability of data and materials}

Not applicable.

\section{Declarations}

Ethics approval and consent to participate

Not applicable.

\section{Consent for publication}

Not applicable.

\section{Competing interests}

The authors declare that they have no competing interests.

\section{Author details}

'Department of Anesthesia and Intensive Care, IRCCS San Raffaele Scientific Institute, Via Olgettina, 60, 20132 Milan, Italy. ${ }^{2}$ Medical Research Institute of New Zealand, Wellington, New Zealand. ${ }^{3}$ Faculty of Medicine, Vita-Salute San Raffaele University, Milan, Italy.
Received: 10 November 2021 Accepted: 11 November 2021

Published online: 27 November 2021

\section{References}

1. Hypothermia after Cardiac Arrest Study Group. Mild therapeutic hypothermia to improve the neurologic outcome after cardiac arrest. N Engl J Med. 2002:346:549-56.

2. Bernard SA, Gray TW, Buist MD, Jones BM, Silvester W, Gutteridge G, et al. Treatment of comatose survivors of out-of-hospital cardiac arrest with induced hypothermia. N Engl J Med. 2002;346:557-63.

3. Dankiewicz J, Cronberg T, Lilja G, Jakobsen JC, Levin H, Ullén S, et al. Hypothermia versus normothermia after out-of-hospital cardiac arrest. N Engl J Med. 2021:384:2283-94.

4. Landoni G, Pieri M, Young PJ, Bellomo R. Why do multicenter randomized controlled trials not confirm the positive findings of single center randomized controlled trials in acute care? Minerva Anestesiol. 2019:85:194-200.

5. Taccone FS, Lascarrou J-B, Skrifvars MB. Targeted temperature management and cardiac arrest after the TTM-2 study. Crit Care. 2021;25:275.

\section{Publisher's Note}

Springer Nature remains neutral with regard to jurisdictional claims in published maps and institutional affiliations.
Ready to submit your research? Choose BMC and benefit from:

- fast, convenient online submission

- thorough peer review by experienced researchers in your field

- rapid publication on acceptance

- support for research data, including large and complex data types

- gold Open Access which fosters wider collaboration and increased citations

- maximum visibility for your research: over $100 \mathrm{M}$ website views per year

At BMC, research is always in progress.

Learn more biomedcentral.com/submissions 